Conceptualising the Loot Box Transaction as a Gamble between the Purchasing Player and the Video Game Company

Leon Y. Xiao [0000-0003-0709-0777]* <leon.xiao.y@gmail.com>

*: Durham Law School, Durham University, Palatine Centre, Stockton Rd, Durham, United Kingdom DH1 3LE

Content Type: Letter to the Editor

Running Head: Conceptualising the Loot Box Transaction as a Gamble

Word count: 725

Conflict of Interest Declaration: None

1 May 2020 


\section{Conceptualising the Loot Box Transaction as a Gamble between the Purchasing Player and the Video Game Company}

To the Editor:

Loot boxes represent a popularly implemented randomised monetisation method in video games, which offers purchasing players virtual rewards of varying value (Zendle et al., 2020). Multiple popular implementations of loot boxes have been argued to be structurally and psychologically similar to gambling (Drummond \& Sauer, 2018). The potential gambling-related harms of loot boxes, and the relationship between loot boxes and gambling have been identified and established in the literature to a limited extent (Brooks \& Clark, 2019; Drummond \& Sauer, 2018; King \& Delfabbro, 2018, 2019; Kristiansen \& Severin, 2019; Larche et al., 2019; Li et al., 2019; Nielsen \& Grabarczyk, 2019; Xiao \& Henderson, 2019; Zendle, Cairns, et al., 2019; Zendle, Meyer, et al., 2019; Zendle \& Cairns, 2018, 2019). These remain areas of active academic research and debate. National gambling regulators have considered whether or not loot boxes constitute gambling under their national laws (Autorité de regulation des jeux en ligne [ARJEL; Regulatory Authority for Online Games] (France), 2018; Belgische Kansspelcommissie [Belgian Gaming Commission], 2018; Digital, Culture, Media and Sport Committee of the House of Commons [DCMS Committee] (UK), 2019; Federal Trade Commission (US), 2019; Kansspelautoriteit [The Netherlands Gaming Authority], 2018; Senate Environment and Communications References Committee (Australia), 2018; UK Gambling Commission, 2017). China has restricted the sale of loot boxes to children by imposing maximum monthly spending limits (Xiao, 2020). Regulatory policies on loot boxes remain forthcoming in many countries and are presently being considered and debated by policy-makers (e.g., in the UK see Prime Minister's Office, 2019).

A conceptual gap in the literature which misleads academics and regulators alike, and which prevents them from evaluating the issue comprehensively, must be clarified. The conceptualisation of the loot box transaction as a gamble has not yet been specified by the literature. The participating parties to this gamble have not been explicitly identified: it is unclear whether it is a gamble between various players, or between a player and the game company. Papers in the literature would generally cite Drummond and Sauer (2018) to assert that loot boxes are structurally similar to gambling (e.g., Zendle, 2019, p. 2; Zendle, Cairns, et al., 2019, p. 184; Zendle, Meyer, et al., 2019, pp. 2-3; Zendle \& Cairns, 2018, p. 2, 2019, 
p. 2). However, the criteria presented in Drummond and Sauer's preliminary paper (2018), if applied presently, in light of subsequent research, would be more restrictive than necessary and potentially misleading.

Academics and regulators currently working on this issue would benefit from being informed by a more inclusive perspective, which specifies that the loot box transaction should be conceptualised as a gamble between the purchasing player and the video game company, rather than conceptualised using the overly restrictive criteria applied by Drummond and Sauer (2018) which included in-game 'Competitive Advantage' as a criterion. The unnecessary consideration of this additional criterion had meant that only loot boxes which provided the purchasing player with some 'competitive advantage' over other players (in multiplayer games), or over a hypothetical comparative version of the purchasing player who did not purchase the loot boxes (in single-player games), were determined to be structurally similar to gambling.

The more inclusive conceptualisation of the loot box transaction as a gamble adheres more to and does not adapt Griffiths' definitional framework for gambling (1995, pp. 1-2), and explicitly identifies the participating parties of the gamble as the player purchasing the loot box and the video game company offering it for sale. The player is risking losing money (when they obtain worthless in-game items) for a chance to obtain rare and valuable items at very little cost, whilst the company is risking having to immediately provide the player with rare and valuable items at an undervalue, and losing out on additional potential sales, for a chance to instead provide the player with worthless in-game items even though they have paid money.

Loot boxes remain the subject of ongoing research and academic debate, and prospective regulation. The more inclusive conceptualisation presented by this Letter does not require a 'competitive advantage' to be provided to the purchasing player by the game company for a gamble to be identified. Accordingly, it would conclude that a higher proportion of loot boxes is structurally similar to gambling, thus allowing academics and regulators to fully assess the true extent of the potential consumer harms caused by loot boxes. 


\section{References}

Autorité de regulation des jeux en ligne [ARJEL; Regulatory Authority for Online Games] (France). (2018). Rapport d'activité 2017-2018 [Activity Report 2017-2018].

Retrieved 1 May 2020, from http://www.arjel.fr/IMG/pdf/rapport-activite-2017.pdf

Belgische Kansspelcommissie [Belgian Gaming Commission]. (2018). Onderzoeksrapport loot boxen [Research Report on Loot Boxes]. Retrieved 1 May 2020, from https://www.gamingcommission.be/opencms/export/sites/default/jhksweb_nl/docume nts/onderzoeksrapport-loot-boxen-final-publicatie.pdf

Brooks, G. A., \& Clark, L. (2019). Associations between loot box use, problematic gaming and gambling, and gambling-related cognitions. Addictive Behaviors, 96, 26-34. https://doi.org/10.1016/j.addbeh.2019.04.009

Digital, Culture, Media and Sport Committee of the House of Commons [DCMS Committee] (UK). (2019). Immersive and Addictive Technologies: Fifteenth Report of Session 2017-19 (HC 1846). Retrieved 1 May 2020, from https://publications.parliament.uk/pa/cm201719/cmselect/cmcumeds/1846/1846.pdf

Drummond, A., \& Sauer, J. D. (2018). Video Game Loot Boxes Are Psychologically Akin to Gambling. Nature Human Behaviour, 2(8), 530-532. https://doi.org/10.1038/s41562018-0360-1

Federal Trade Commission (US). (2019, August 7). Inside the Game: Unlocking the Consumer Issues Surrounding Loot Boxes. Public Workshop, Washington, DC, US. Retrieved 1 May 2020, from https://www.ftc.gov/news-events/events-calendar/insidegame-unlocking-consumer-issues-surrounding-loot-boxes

Griffiths, M. D. (1995). Adolescent Gambling. Routledge.

Kansspelautoriteit [The Netherlands Gaming Authority]. (2018). Onderzoek naar loot boxes: Een buit of een last? [Study into Loot Boxes: A Treasure or a Burden?]. Retrieved 1 May 2020, from https://www.kansspelautoriteit.nl/publish/library/6/onderzoek_naar_loot_boxes_een_buit_of_een_last_-_nl.pdf

King, D. L., \& Delfabbro, P. H. (2018). Predatory Monetization Schemes in Video Games (e.g. 'Loot Boxes') and Internet Gaming Disorder. Addiction, 113(11), 1967-1969. https://doi.org/10.1111/add.14286

King, D. L., \& Delfabbro, P. H. (2019). Video Game Monetization (e.g., 'Loot Boxes'): A Blueprint for Practical Social Responsibility Measures. International Journal of Mental Health and Addiction, 17(1), 166-179. https://doi.org/10.1007/s11469-0180009-3

Kristiansen, S., \& Severin, M. C. (2019). Loot box engagement and problem gambling among adolescent gamers: Findings from a national survey. Addictive Behaviors, 103, 106254. https://doi.org/10.1016/j.addbeh.2019.106254

Larche, C. J., Chini, K., Lee, C., Dixon, M. J., \& Fernandes, M. (2019). Rare Loot Box Rewards Trigger Larger Arousal and Reward Responses, and Greater Urge to Open More Loot Boxes. Journal of Gambling Studies. https://doi.org/10.1007/s10899-01909913-5

Li, W., Mills, D., \& Nower, L. (2019). The Relationship of Loot Box Purchases to Problem Video Gaming and Problem Gambling. Addictive Behaviors, 97, 27-34. https://doi.org/10.1016/j.addbeh.2019.05.016

Nielsen, R. K. L., \& Grabarczyk, P. (2019). Are Loot Boxes Gambling? Random Reward Mechanisms in Video Games. Transactions of the Digital Games Research Association, 4(3), 171-207. https://doi.org/10.26503/todigra.v4i3.104

Prime Minister's Office. (2019). Queen's Speech December 2019-Background briefing notes. Retrieved 1 May 2020, from 
https://assets.publishing.service.gov.uk/government/uploads/system/uploads/attachme nt_data/file/853886/Queen_s_Speech_December_2019_-

background_briefing_notes.pdf

Senate Environment and Communications References Committee (Australia). (2018).

Gaming Micro-Transactions for Chance-based Items. Retrieved 1 May 2020, from

https://www.aph.gov.au/Parliamentary_Business/Committees/Senate/Environment_an

d_Communications/Gamingmicro-transactions/Report

UK Gambling Commission. (2017). Virtual Currencies, eSports and Social Gaming-

Position Paper. Retrieved 1 May 2020, from

http://www.gamblingcommission.gov.uk/PDF/Virtual-currencies-eSports-and-socialcasino-gaming.pdf

Xiao, L. Y. (2020). People's Republic of China Legal Update: The Notice on the Prevention of Online Gaming Addiction in Juveniles (Published October 25, 2019, Effective November 1, 2019). Gaming Law Review, 24(1), 51-53. https://doi.org/10.1089/glr2.2019.0002

Xiao, L. Y., \& Henderson, L. L. (2019). Towards an Ethical Game Design Solution to Loot Boxes: A Commentary on King and Delfabbro. International Journal of Mental Health and Addiction. Advance online publication. https://doi.org/10.1007/s11469019-00164-4

Zendle, D. (2019). Problem gamblers spend less money when loot boxes are removed from a game: A before and after study of Heroes of the Storm. PeerJ, 7, e7700. https://doi.org/10.7717/peerj.7700

Zendle, D., \& Cairns, P. (2018). Video Game Loot Boxes Are Linked to Problem Gambling: Results of a Large-Scale Survey. PLoS One 13(11): E0206767. https://doi.org/10.1371/journal.pone.0206767

Zendle, D., \& Cairns, P. (2019). Loot Boxes Are Again Linked to Problem Gambling: Results of a Replication Study. PLoS One 14(3): E0213194. https://doi.org/10.1371/journal.pone.0213194

Zendle, D., Cairns, P., Barnett, H., \& McCall, C. (2019). Paying for Loot Boxes is Linked to Problem Gambling, Regardless of Specific Features Like Cash-out and Pay-to-win. Computers in Human Behavior, 102, 181-191. https://doi.org/10.1016/j.chb.2019.07.003

Zendle, D., Meyer, R., Cairns, P., Waters, S., \& Ballou, N. (2020). The prevalence of loot boxes in mobile and desktop games. Addiction. Advance online publication. https://doi.org/10.1111/add.14973

Zendle, D., Meyer, R., \& Over, H. (2019). Adolescents and Loot Boxes: Links With Problem Gambling and Motivations for Purchase. Royal Society Open Science 6: 190049. https://doi.org/10.1098/rsos.190049 